\title{
Soap-Making Process Improvement: Including Social, Cultural and Resource Constraints in the Engineering Design Process
}

\author{
Grace Burleson \\ HBS Mechanical Engineering \\ Oregon State University \\ Burleson.grace@gmail.com
}

\author{
Brian Butcher \\ BS Mechanical Engineering \\ Oregon State University \\ Brian.butcher.91@gmail.com
}

\author{
Brianna Goodwin \\ BS Mechanical Engineering \\ Oregon State University \\ Goodwb@uw.edu
}

\author{
Kendra Sharp \\ Professor, Humanitarian Engineering \\ Oregon State University \\ Kendra.sharp@oregonstate.edu
}

\author{
Bonnie Ruder \\ PhD Candidate, Applied Anthropology \\ Oregon State University \\ Bonnieruder@gmail.com
}

Abstract - The engineering profession is increasingly recognizing that engineers' abilities to utilize a systems perspective and collaborate on multidisciplinary teams are critical professional competencies required to solve contemporary engineering challenges. Understanding context, including but not limited to social and cultural context, is one aspect of systems thinking that is important to effective problem-solving, yet such training is not yet standard in our engineering curricula. Humanitarian engineering-related capstone design projects offer both hands-on and field opportunities to integrate social and cultural appropriateness into a formal engineering design curriculum. Over the 2015-2016 academic year, Oregon State University offered a capstone project aimed at optimizing and implementing an improved soap-making process for TERREWODE, a non-governmental organization in Uganda. The ultimate goal of this soap-making project was to expand income-generating opportunities for victims and survivors of obstetric fistula. The project consisted of a six-month, on-campus design phase and a three-week field implementation and research trip in Soroti, Uganda. Six Social Justice (SJ) criteria were used in assessing project context and developing design requirements. Throughout the design phase, experimental testing drove the majority of design decisions. During field implementation and research, the three-student capstone design team worked closely with TERREWODE and their members to optimize the process, understand cultural conditions, and recommend options for potential local solar power systems.

Index Terms - Service learning, Senior capstone project, Humanitarian Engineering, Uganda, Design for Global Development, Social Impact

\section{INTRODUCTION}

Professionals agree that to tackle increasingly complex challenges, effective engineers need to be able to work with diverse teams and understand the impact of context, including social, cultural, economic and other factors on engineering constraints ${ }^{1}$. Further they agree that practicing 
socially and culturally-appropriate product design is essential to the future of engineering ${ }^{2}$. As stated recently by Abbas El-Zein:

"It will be a bright day for our profession when we start producing more engineers who... have the will and the intellectual capacity to engage with bigger questions about the ethics, politics and social ramifications of their inventions"

Many academic engineering programs are responding to these needs by offering additional service learning and cross-cultural experiences to their students. Experiences such as these are shown to have positive effects on students' academic performance, value development, selfefficacy, leadership, and plans to continue with service upon graduation ${ }^{4,5}$. Particularly, skills developed through international experiences, which include communication, problem solving, and teamwork ${ }^{6}$, align with those sought by employers of college graduates ${ }^{7}$.

University students are becoming more interested in social impact project and service learning as $72 \%$ claim that having a job with social impact is a higher priority than having children, a prestigious career, or wealth ${ }^{8,9}$. Universities are responding to this interest by incorporating more service-learning opportunities, such as clubs and class projects, and humanitarian-focused engineering curriculum in their education programs ${ }^{10}$. For example, Engineers Without Borders USA (EWB-USA), a service-based organization, has grown to include more than 15,900 volunteers and 300 college and university chapters across the United States since its inception in $2002^{11,12}$.

In addition to themed courses, Oregon State University's Humanitarian Engineering Program is now offering humanitarian engineering-themed capstone design project opportunities, such as the project described in this paper. This capstone project comprised the design and testing of improvements to an initial soap-making process used by our partner organization, TERREWODE (Soroti, Uganda). These process improvements can be adopted and further refined by TERREWODE as they expand their soap-making efforts. The Oregon State University (OSU) student team of three Mechanical Engineering seniors collaborated with TERREWODE, a non-governmental organization (NGO) in Uganda, and an Oregon-based team of professionals with expertise in visual arts, business, anthropology and the medical condition known as obstetric fistula. Importantly, the concept of adding soap-making and a goat milk based soap product to their existing income-generating activities was generated by Alice Emasu, the director of TERREWODE, and supported by a series of efforts from organizational partners (including the broader Oregon-based team of professionals outside of OSU).

This article begins by providing relevant project background. Next, the 6-month campusbased design and experimentation phase is described, discussing how the project adhered to the standard 6-month capstone design curriculum and how the design process was adapted to attend to the social, cultural, and resource context. This is followed by a description and discussion of the field-based research and implementation of process improvements in June 2016 in Soroti, Uganda, including reflection and recommendations on how to improve the educational value and execution of similar projects. 


\section{BACKGROUND}

To provide context, background on the relevant educational environment at Oregon State University, the history of the project including the TERREWODE organization and partners, partner roles, and overall project goals is provided.

\section{Social and Cultural Context in Design Education}

Typical engineering education in the USA produces college graduates who are no more likely than the rest of the population to be interested in current political issues and involved in effecting positive change in their communities ${ }^{13}$. Although engineering for social impact has been gaining interest in universities, many programs still heavily focus on the technical aspects of engineering design, with limited engagement in social matters and/or cross-cultural contexts ${ }^{14}$. There are a number of USA and overseas universities with formal academic programs in humanitarian engineering or engineering for global development programs (e.g. Colorado School of Mines ${ }^{15}$, Pennsylvania State University ${ }^{16}$, Ohio State University ${ }^{17}$, University of California-Berkeley ${ }^{18}$, Massachusetts Institute of Technology ${ }^{19}$, University of Canterbury-New Zealand ${ }^{20}$, and Australian National University ${ }^{21}$, among others). Using engineering projects as a means for service learning has a well-known impact on students' academic experience by generating outcomes such as improved context understanding, problem analysis, critical thinking, and cognitive development ${ }^{22}$. STEM service learning projects have been shown to contribute to the development of strong communication skills and a deeper understanding of their field in undergraduate engineering students ${ }^{23}$. These skills are transferable to any engineering career, humanitarian or other. In 2010, prior to the issuing of updated Sustainable Development Goals ${ }^{24}$, UNESCO estimated that 2.5 million new engineers and technologists were needed by 2015 to achieve the Millennium Development Goal of improved access to clean water in sub-Saharan Africa alone $^{25}$. In 2013, Arup, a major global consulting firm of engineers, designers, planners, and project managers grew its employee base by $7 \%^{26}$. McKinsey analysts estimate that the market share of large multinationals in emerging markets will grow from $20 \%$ to $50 \%$ in the next decade $^{27}$ and positions within emerging economies will serve increasingly as a host for their science and engineering clusters ${ }^{28}$. Thus, graduates who are both technically competent and well versed in global competencies and cross-cultural communication are expected to be in demand in the engineering profession.

\section{Humanitarian Engineering at Oregon State University}

The Humanitarian Engineering program at Oregon State University (OSU) aims to develop engineering and technology-based solutions to improve the human condition, namely through improved ability to meet basic human needs, improved quality of life, or an improved level of community resilience; all while providing OSU students with empowering experiences through service learning. In 2015, OSU created one of the only endowed professorships in this emerging field of service learning in engineering ${ }^{29}$. Since then, the program facilitates new coursework offerings, projects, and research opportunities for students in a variety of fields such as 
mechanical, industrial, civil, electrical, water resources, environmental engineering, as well as public health, education, anthropology, and geography ${ }^{30}$.

\section{TERREWODE, Local Context and Partners}

TERREWODE is a non-governmental organization (NGO) in Soroti, Uganda working to eradicate obstetric fistula in local communities and provide income-generating skills training to the affected women. Obstetric fistula is a preventable medical condition that occurs during prolonged, obstructed labor. Women suffering from this condition experience urinary and/or bowel incontinence and are often ostracized from their community ${ }^{31}$. In Uganda, approximately 200,000 women suffer from obstetric fistula, with 1,900 new cases expected annually ${ }^{32}$. TERREWODE works to provide these women necessary funds for medical treatment and implement a means of empowerment and reintegration into their communities. Women in the reintegration program participate in a two-week training where they receive mental health counseling, learn various income-generating skills, and gain experience in money management. Additionally, as part of TERREWODE's reintegration and identification programs, Solidarity Groups exist in villages surrounding Soroti. These groups may consist of fistula survivors, their families, and neighbors. The purpose of the Solidarity Groups is not only to support the survivors, but also to raise community awareness and fight against child marriage, a leading cause of obstetric fistula ${ }^{33}$.

In early 2015, visual artist Joni Kabana visited Soroti, Uganda with gifts of Oregon handmade goat-milk soap, for the TERREWODE employees. Executive director Alice Emasu became interested in the idea of making the product locally in Uganda to financially support the organization's members. She was especially drawn to the potential appeal of goat-milk soap as it is often seen as a luxury item and sold with high profit margins. She quickly learned that Ugandan goat breeds are non-dairy rearing and connected with Heifer International, an international NGO striving to mitigate world hunger through the provision of milk-producing livestock to low-resource communities.

There are roughly 4 million goats in Uganda ${ }^{34}$, ranging a variety of breeds, with an estimated 41,000 tons of goat milk produced each year ${ }^{35}$. However, the goat breeds that Ugandan villagers have the means to acquire, such as the Muende and Small East African goat, are non-dairyrearing $^{36}$. To support TERREWODE's mission, Heifer International imported Saanan goats from Ireland in 2015 and trained Ugandan staff in taking care of them ${ }^{37}$. Goats were brought to five villages with TERREWODE Solidarity Groups.

Other partnering personnel and organizations include Dardinelle Troen, colleague of Kabana and Creative Director at Ditroen Inc. in Portland, Oregon (USA); Bonnie Ruder, PhD candidate in Applied Anthropology at OSU and director of the Ugandan Fistula Fund; OSU Humanitarian Engineering and College of Business; and MAPLE Microdevelopment, an NGO based in Mbale, Uganda focusing on local entrepreneurship and sustainable businesses. Table 1 presents the various stakeholders and describes their role with respect to the OSU-sponsored capstone design soap-making process improvement team project. (These same stakeholders have somewhat different roles in terms of TERREWODE's envisioned soap-making and selling social enterprise. For example, the end-users of this capstone project are the women making the soap, as noted in Table 1. The end-users of the final soap product, however, are the targeted customer.) 
International Journal for Service Learning in Engineering,

Humanitarian Engineering and Social Entrepreneurship

Vol. 12, No. 2, pp. 81-102, Fall 2017

ISSN 1555-9033

TABLE 1

STAKEHOLDERS AND THEIR IDENTIFIED ROLES IN THE SOAP-MAKING PROJECT

\begin{tabular}{|l|l|l|}
\hline \multicolumn{1}{|c|}{ Stakeholder } & \multicolumn{1}{|c|}{ Location } & \multicolumn{1}{c|}{ Role } \\
\hline End-users & Soroti, Uganda & $\begin{array}{l}\text { To be the main beneficiaries of the soap-making process } \\
\text { improvement project } \\
\text { - To participate in implementation trials of improvements to } \\
\text { the soap-making process and provide feedback }\end{array}$ \\
\hline TERREWODE & Soroti, Uganda & $\begin{array}{l}\text { T To provide the team with resources to implement and test } \\
\text { soap-making process improvements in Uganda } \\
\text { - To provide feedback to the team during fieldwork } \\
\text { - To follow the OSU capstone design curriculum while } \\
\text { improving the soap-making process }\end{array}$ \\
\hline $\begin{array}{l}\text { OSU engineering } \\
\text { mentors }\end{array}$ & $\begin{array}{l}\text { Corvallis, Oregon, } \\
\text { USA }\end{array}$ & $\begin{array}{l}\text { Corvallis, Oregon, } \\
\text { USA }\end{array}$ \\
\hline Bonnie Ruder & $\begin{array}{l}\text { Corvallis, Oregon, the student team through the capstone design } \\
\text { USA }\end{array}$ & $\begin{array}{l}\text { To aid communication between TERREWODE and the } \\
\text { capstone team }\end{array}$ \\
\hline $\begin{array}{l}\text { To provide the team with contextual information regarding } \\
\text { the end-users }\end{array}$ \\
Joni Kabana
\end{tabular}

\section{Project Goals}

This ultimate goal of this soap-making project was to expand income-generating opportunities for women served by TERREWODE. Specifically, the project consisted of a six-month, oncampus design phase to improve a soap-making process, and a three-week field implementation and research trip in Soroti, Uganda to provide consultation for process improvements and solar energy recommendations.

\section{Soap-Making Processes for Small-Scale Organizations/Enterprises}

We considered two main soap-making processes for this project: the hot process and cold process. Figure 1 displays the two processes and their differences. Both the hot and cold soap 
International Journal for Service Learning in Engineering,

Humanitarian Engineering and Social Entrepreneurship

Vol. 12, No. 2, pp. 81-102, Fall 2017

ISSN 1555-9033

making processes involve mixing fats with a strong alkali. Both processes include the same ingredients, which include:

- Liquid fat: oils from plants (such as olive and palm)

- Solid fat: animal fat or shea butter

- Lye: an alkali consisting of sodium hydroxide or potassium hydroxide

- Goat's milk

- Fragrances and colorants: used for aesthetic purposes

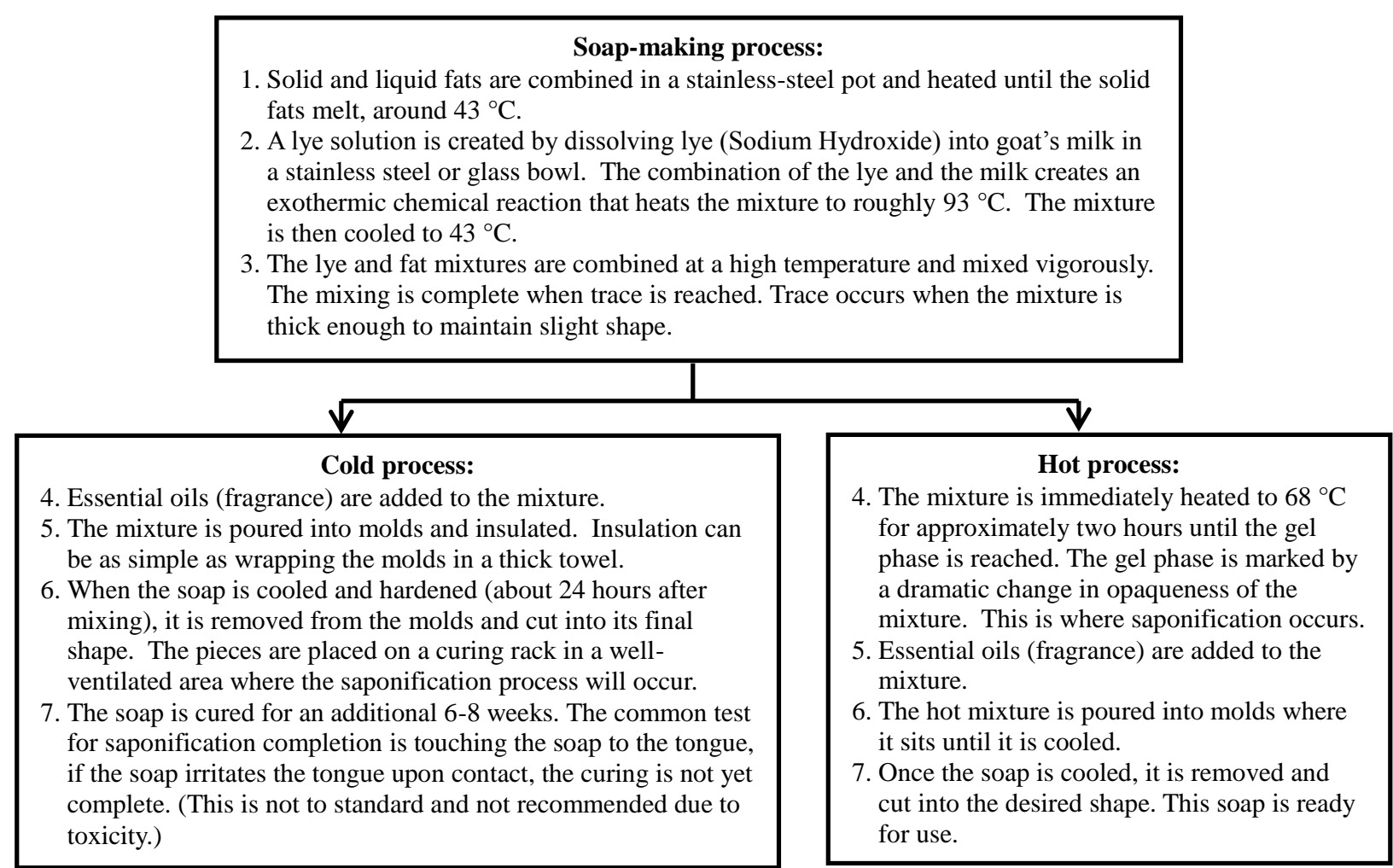

FIGURE 1

THE SOAP-MAKING PROCESS STEPS FOR BOTH HOT AND COLD PROCESSES

A chemical reaction between the goat's milk and lye allows saponification to occur, resulting in soap. In the hot process, saponification occurs while the mixture is held at $68{ }^{\circ} \mathrm{C}$ until the gel phase occurs. The gel phase is visually indicated by a dramatic change in opaqueness of the mixture, taking roughly two hours. If the soap mixture does not reach or maintain this temperature, saponification will not occur and the soap will not be safe due to the presence of remaining lye. If the temperature is increased over $68{ }^{\circ} \mathrm{C}$, the mixture will burn, resulting in unusable soap. On the contrary, saponification during the cold process occurs after the soap mixing process, during an extended curing period which can last up to two months ${ }^{38}$.

Due to the availability of appropriate resources and low start-up capital, soap-making can be a lucrative and successful venture in sub-Saharan Africa ${ }^{39,40,41}$. The cold process is recommended 
by small-scale enterprise soap makers in low-resource contexts, particularly in tropical regions due to quick solidification of local oils ${ }^{42}$. Engineers Without Borders-UK published a soapmaking manual and recommended the cold process for their chapters participating in projects in Tanzania, South Africa, and Nigeria ${ }^{43}$. Specifically, in Uganda, small soap and detergent businesses have been successful ${ }^{44}$.

\section{ON-CAMPUS DESIGN PHASE}

During the six-month on-campus phase, the team followed the OSU capstone design course sequence, ME 497-498 ${ }^{45}$, with specific research and design process, shown in Figure 2, following the Quality Function Deployment (QFD) House of Quality model with weekly deliverables, meetings, and presentations.

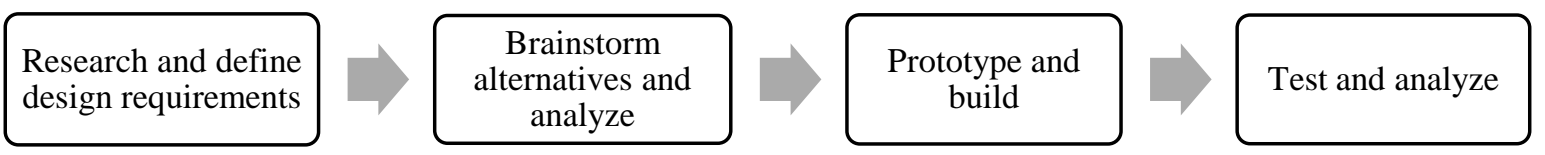

FIGURE 2

DESIGN PROCESS FOR OSU SENIOR CAPSTONE PROJECT

\section{Defining Design Requirements}

The House of Quality method includes identifying customer needs into Customer Requirements (CR), then, deriving Engineering Specifications (ES) to form a relationship between customer needs and testable attributes ${ }^{46}$. Unlike traditional senior capstone teams, this team assessed the project parameters using the six Social Justice (SJ) criteria outlined by Leydens and Lucena in $2014^{47}$. The SJ criteria include: listening contextually, identifying structural conditions, acknowledging political agency/mobilizing power, increasing opportunities and resources, reducing imposed risks and harms, and enhancing human capabilities.

1. Listening contextually - The capstone team sought to understand the multidimensional aspects of the goat-milk soap project. By meeting with experts in a variety of disciplines, the team was better able to establish user needs and project requirements. Personal communication with Bonnie Ruder, PhD candidate in Applied Anthropology at OSU and director of the Ugandan Fistula Fund, informed the team's understanding of the sociocultural effects of obstetric fistula for women in Uganda and the current efforts in place to mitigate adversity. The team met with Ron Severson, Senior Instructor of Management at the University of Oregon and director of MAPLE Microdevelopment, to learn about the development of sustainable business models and available forms of energy, such as solar power, in Uganda. Additional customer requirements were established through personal communication with Alice Emasu, Joni Kabana, Dardinelle Troen, and Nordica MacCarty. 
2. Identifying structural conditions - Interviews and correspondences with experts provided the team with information on the economic, cultural, and other conditions that either enabled or constrained the aspirations of the members of TERREWODE. For example, women who have suffered from obstetric fistula are sometimes unable to perform physically demanding tasks ${ }^{48}$. To account for this concern, the capstone team created two design requirements related to the weight of the system and its ergonomics. In Soroti, grid electricity is highly unreliable and the local market is flooded with poorly manufactured solar components ${ }^{49}$. To account for this structural condition, the capstone team designed their system to accommodate these concerns by communicating with experts and researching locally available solutions to provide informed recommendations to TERREWODE during field implementation.

3. Acknowledging political agency/mobilizing power - The team acknowledged that the addition of new technologies inherently serves one group of people more than others. Here, the team aimed to ensure the TERREWODE members were the stakeholder group who gained the most opportunities and resources from this project.

4. Increasing opportunities and resources - In working to increase the potential of the TERREWODE women, the capstone team created design requirements to minimize waste, increase efficiency, and reduce operation time.

5. Reducing imposed risks and harms - The team created design requirements to increase the safety and consistency of the process. With advice from anthropologist Bonnie Ruder, the team sought to gain empathy for the end users, specifically women who have suffered from obstetric fistula, to better understand their daily struggles. This knowledge informed the team's perspective of the potential risks and harms specific to their customers that may be overlooked in traditional engineering design.

6. Enhancing human capabilities - The end goal of this project was to empower women who have suffered from obstetric fistula through gaining soap-making skills as a potential method of income generation. The team sought to accomplish goal this by designing a system that was enjoyable for the women to participate in, did not impose any additional risks or harms to their health, and created a viable product for income generation.

After stepping through the six SJ criteria, the team defined 15 Customer Requirements (CR) and 20 Engineering Specifications (ES), shown in Table 2. These lists were used to shape the design process through a weighted-design matrix. 
TABLE 2

\section{CRs AND ESs FOR SOAP-MAKING CAPSTONE PROJECT}

\footnotetext{
Customer Requirements (CR)

1. The device must create quality soap

2. Two women must be able to carry the device

3. The device must be ergonomic for the user and women carrying it

4. The device and soap process must use resources readily available in Uganda

5. The waste must be easily disposable in Soroti, Uganda.

6. The device must be consistent

7. The device must be durable

8. The device must be easily maintainable

9. The device must have theft protection (key or lock system)

10. The device and soap making process must be safe for users

11. The device must be inexpensive to manufacture

12. The process must take minimal operator time to manufacture soap

13. The device must be simple and easy to manufacture

14. The soap making process and device must be scalable for future improvements

15. The process must create a sellable soap product, which allows the women to generate income
}

\section{Engineering Specifications (ES)}

1. Hardness of soap

2. $\mathrm{pH}$ of soap

3. Volume of batch size

4. Input percentage converted to waste

5. Manufacturing cost per bar

6. Retail value

7. Mixing capacity

8. Batch cycle time

9. Device weight

10. Number of handles

11. Operating height

12. Product can withstand a weight being placed on it

13. Cycles prior to a part failure

14. Machining time of creating one device

15. Manufacturing time of creating one machine

16. External surface heat

17. Soap lead time

18. Area of pot opening when lid is closed

19. Combustion exhaust released in working environment

20. Volume of hazardous waste per batch

\section{Experimental Testing as a Design Selection Method}

While other teams in capstone design course sections typically relied on computational modeling for design selection, this senior team used empirical prototyping throughout this phase of the project. First, the team determined which soap making process, hot or cold, would be most suitable for this specific context by testing each process' labor intensity, repeatability, and simplicity.

Using a StoveTec (Cottage Grove, Oregon, USA) wood-burning cookstove, the team created soap using both processes. The tools, batch size, power source, and ambient conditions all remained constant between tests. In rural Uganda, wood-burning three-stone fires are the most common form of heating due to their accessibility and reliability. However, the StoveTec cookstove is recommended as a heat source because it has a much higher thermal efficiency and produces fewer emissions 50 .

The first test addressed the concern of keeping the soap mixture at the desired $68{ }^{\circ} \mathrm{C}$ during the hot process for two hours. (In the cold process, this step is not required). For this temperature stability test, two batches of hot process soap were made, one on the StoveTec cookstove and the other on a Coleman gas-burning stove. An attendant at each stove attempted to keep the soap mixture at the desired $68{ }^{\circ} \mathrm{C}$ until the gelling phase occurred. Time to gelling is 
typically two hours if the temperature can be maintained with minimal deviation. The temperature of the mixture on each stove was recorded every two minutes until gelling occurred, indicating saponification. The average temperatures of the soap mixtures cooked on the StoveTec and the Coleman stoves were $60.8{ }^{\circ} \mathrm{C}$ and $70.9{ }^{\circ} \mathrm{C}$, respectively. On both stoves, the temperature of the mixture varied greatly, both above and below the target temperature of $68^{\circ} \mathrm{C}$, demonstrating the inconsistency of the hot process over wood- and gas-burning stoves. During testing, a significant decrease in the temperature in the wood stove data occurred between 40 and 60 minutes. This decrease occurred due to an over correction when the temperature spiked around the 30 minute mark. After the spike, the heat source was removed from the soap-making setup. Once it was recognized that the heat needed to be re-added, the attendant struggled to get the fire going at a sufficient level to warm the soap but not cause it to burn. The ambient temperature was $-2{ }^{\circ} \mathrm{C}$ while performing this temperature stability experiment, causing the temperature to decline faster than expected. This caused the temperature of the soap mixture to fluctuate due to the cold ambient temperature. The team recognized that testing outside in cold weather was not representative of life in rural Uganda, where daily temperature is much higher ${ }^{51}$.

To further assess the hot process, another experiment was conducted at the Aprovecho Research Center in Cottage Grove, Oregon. The experiment was performed in a temperature and humidity controlled room and wood was cut into smaller pieces to ensure only the necessary amount of heat needed was provided to the system. Temperature of the mixture was recorded continuously using Aprovecho's equipment, the Laboratory Emissions Monitoring System $(\text { LEMS })^{52}$. The results from testing two experiments outdoors and one experiment in the controlled environment can be seen in Figure 3. Although the data from Aprovecho shows more consistent heating, there is still a large spike between the 80 and 120 minute mark. This is due to the exothermic reaction that occurs in the soap. No heat was applied to the system between 80 minutes and 120 minutes, but the temperature continued to rise. It is important to note that this process needed constant attention and an attendant diligently monitored the temperature throughout the entire time period. 


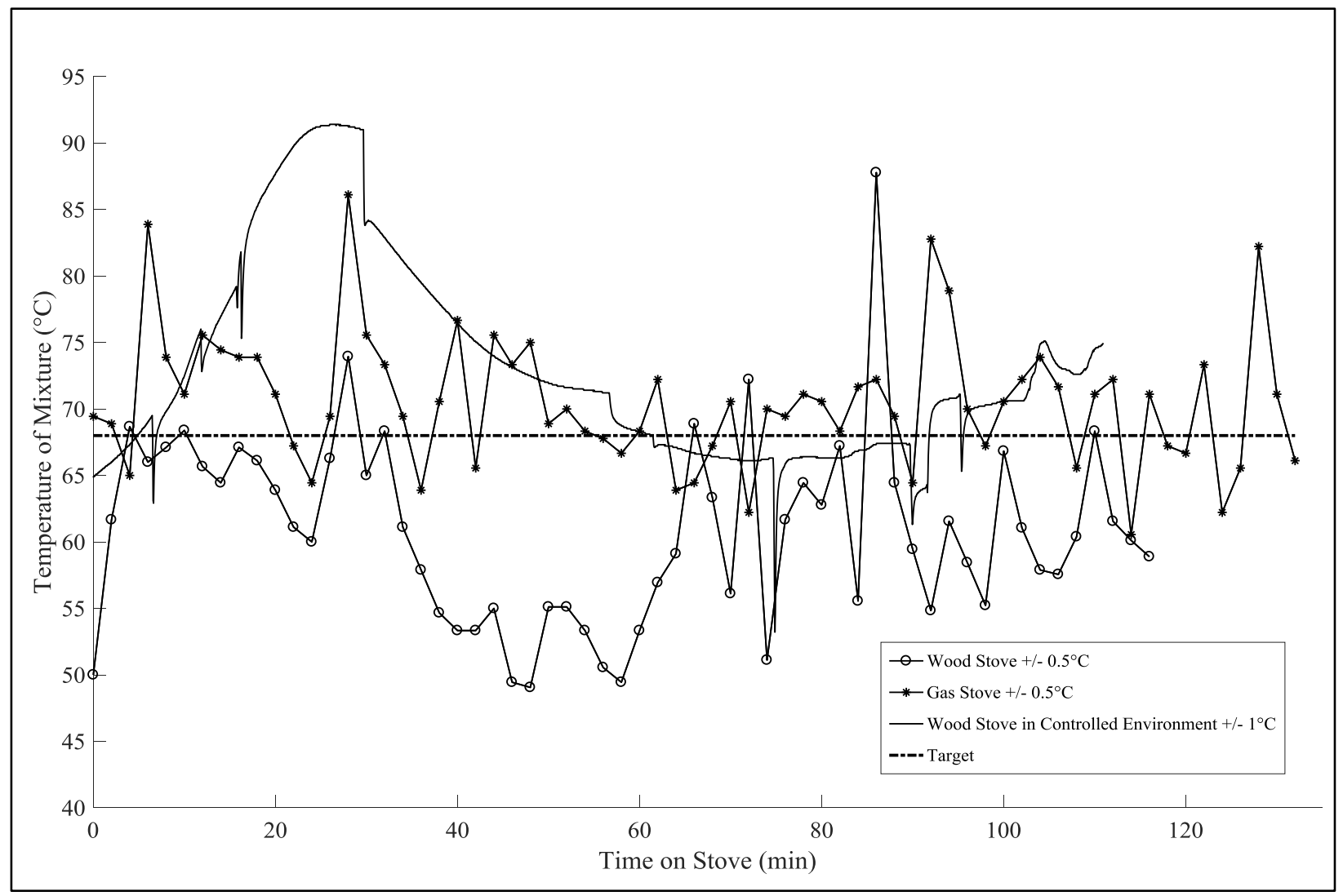

FIGURE 3

\section{EXPERIMENTAL TEMPERATURE DATA FOR SOAP DURING HOT PROCESS SOAP- MAKING WHILE USING A WOOD STOVE AND GAS STOVE}

Additionally, emissions tests of both processes were performed at the Aprovecho Research Center. Using Aprovecho's LEMS testing equipment, the team measured the amount of carbon monoxide and carbon dioxide generated by each soap making process in order to analyze each based on environmental and health effects. The results from this trial can be seen in Figure 4. To analyze the emissions produced, the experiment can be broken up into the cold process, which would occur between 35 and 55 minutes, and the hot process, which would occur between 35 and 188 minutes. Because both processes begin with the same procedure of heating oils, the resulting emissions is the same for both hot and cold processes between 35 and 55 minutes. Then, the cold process no longer requires a heat source and does not produce any more stove emissions whereas the hot process continues to heat the mixture over the stove for two hours. Both processes meet Occupational Safety and Health Administration (OSHA) standards for health and safety ${ }^{53}$.

Based on the difficulty of maintaining a consistent temperature with the locally available resource of wood-burning cook stoves, the inconsistency of the quality of hot-process soap, the labor-intensity, and the greater emissions output, the hot process was deemed less desirable. Thus, the cold process was recommended for the TERREWODE soap-making project. 


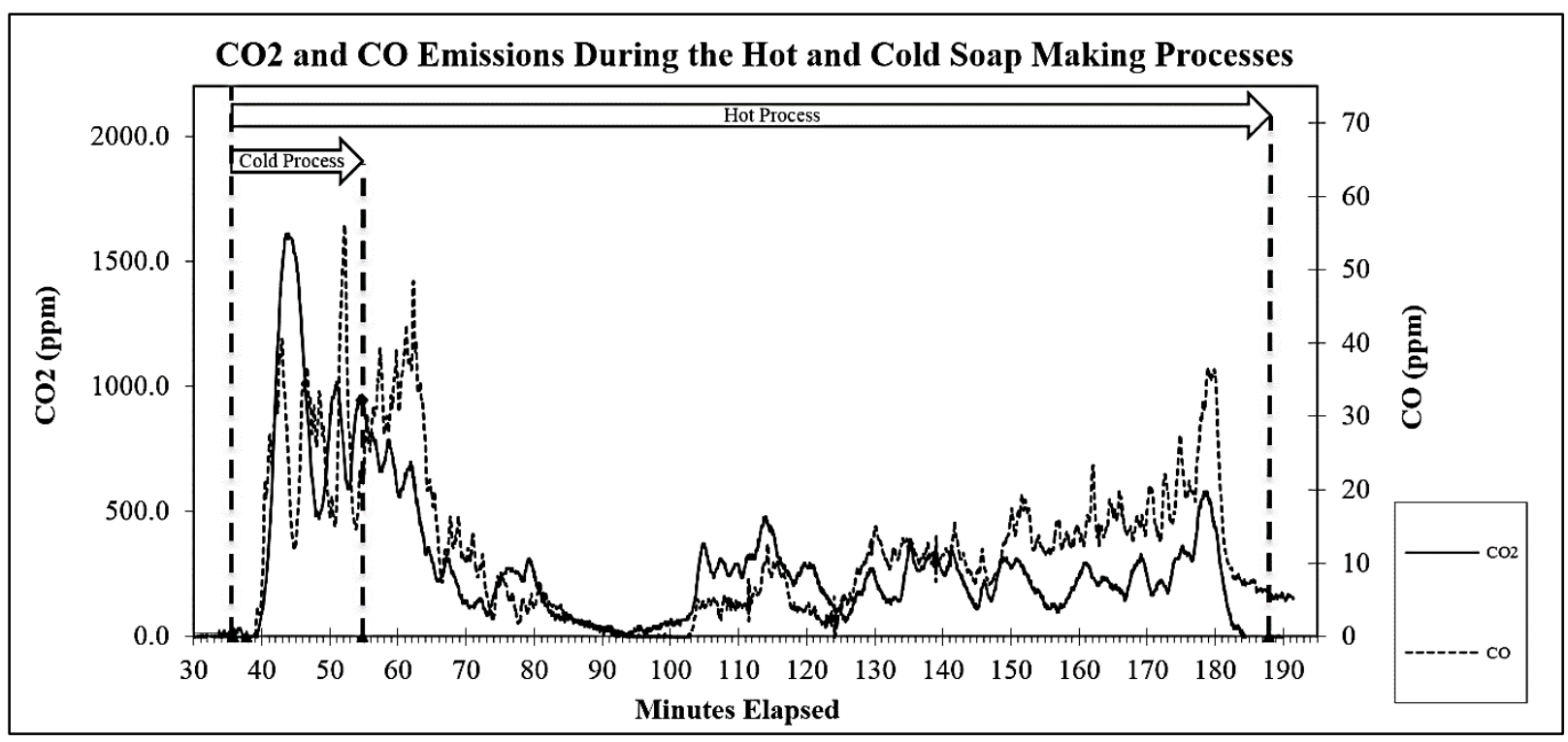

FIGURE 4

\section{CARBON MONIXDE AND CARBON DIOXIDE EMISSIONS FOR COLD AND HOT PROCESS SOAP MIXTURE}

Both the cold and hot soap making processes require vigorous mixing of lye and fat mixtures. Due to unreliable electricity in Soroti and surrounding villages, alternative non-traditional power sources for the mixer were investigated ${ }^{54}$. After considerable research, the design team focused on comparing solar power and human power for the required mixing. Solar power is obtained using solar panels placed in direct sunlight, while human power is obtained through physically spinning a shaft.

When investigating human powered options, a pedaling method was considered to maximize the power output. A human powered bike mixer used for creating soap has already been developed for use in Nigeria ${ }^{55}$, suggesting that a human-powered mixer is feasible and can be executed in a similar fashion in other countries in sub-Saharan Africa. Although there are many advantages to this design, a substantial deterrent is the cultural appropriateness of the design and whether or not the women want to exert additional physical activity in the soap-making process. There was also concern regarding the ability of recovering fistula patients to participate in the biking, as discussed in the analysis of the six SJ criteria. Considering our concerns about cultural and physical appropriateness, the capstone team refrained from designing the system with a human power source.

Solar power was identified as a potential option due to the availability in Uganda and approval from TERREWODE leadership. Implementation of solar does not require strenuous physical activity and is widely available and accepted across Uganda. However, solar power introduces additional challenges regarding the design and total cost of the system. Using recycled solar components from the Phoenix Solar Car team, the capstone team designed, assembled, and tested a solar array at their university. The cells, Sun Power C60 (bin J), were rated at approximately $3.42 \mathrm{~W}$ and $0.582 \mathrm{~V}$ and were pre encapsulated by the Solar Car Team. 
Subsequently, 96 cells were used to achieve a solar array with an output of approximately 329 $\mathrm{W}$, enough to power the $200 \mathrm{~W}$ immersion blender.

The cells were configured into three parallel panels, each one with 32 individual solar cells, with $18.6 \mathrm{~V}$ output at 5.9 A. Between each parallel array, a diode was inserted in order to prevent damaging the cells in the event that one array is producing less power than the other two.

The three panels were split between two pieces of plywood, then connected and channeled through the maximum power point tracker (MPPT), $12 \mathrm{~V}$ battery, and inverter to run the $200 \mathrm{~W}$ immersion blender at $120 \mathrm{~V} \mathrm{AC}$. Plugs were installed on all of the wires so that the kit could easily be disassembled for transportation. A circuit diagram of the solar system is presented in Figure 5 along with a photo of the completed array.
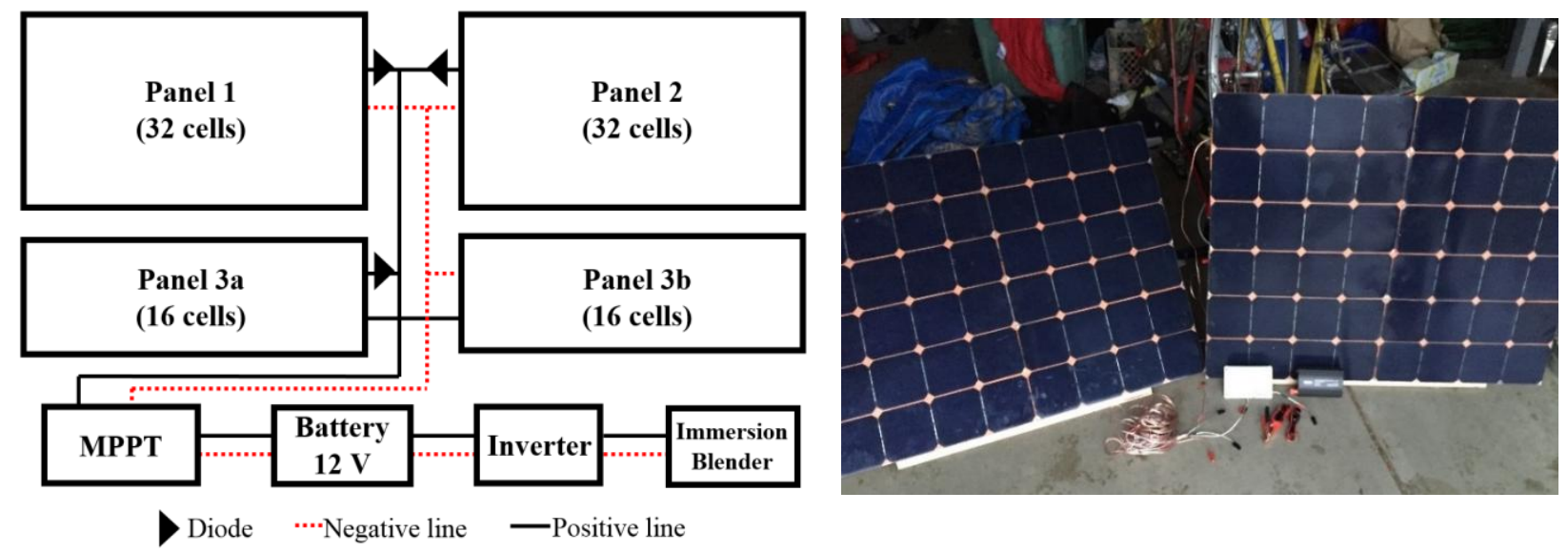

FIGURE 5

\section{LEFT: ELECTRICAL LAYOUT OF THE SOLAR SET UP USED BY THE TEAM RIGHT: A PHOTO OF THE SOLAR PANELS, MPPT, AND WIRING}

\section{Final Design Specifications}

After six months of following the SJ criteria, testing, validation, and frequent communications with TERREWODE to discuss tradeoffs, the design team arrived at a final soap-making process. One of the primary decisions, namely the use of the hot or cold process, was dictated by an especially strong preference for the simpler, cold process by TERREWODE and other project stakeholders. The final soap-making process for one batch is described here:

1. Ensure all soap makers are wearing personal protective equipment (PPE) including safety glasses and gloves.

2. Pour the oil (liquid fat) and shea butter (solid fat) together in a large pot.

3. Using a wooden spoon break the solid fats into smaller pieces.

4. Put the pot on a cook stove and heat until all solid fats are melted (about $43{ }^{\circ} \mathrm{C}$ )

5. Pour the goat's milk into the glass mixing bowl. Slowly add lye with a wooden spoon during the process. It is critical follow this specific order of ingredients because the mixing of the lye and liquids is a chemical reaction and results in a temperature increase to roughly $93{ }^{\circ} \mathrm{C}$ before it is cooled to $43{ }^{\circ} \mathrm{C}$. Carelessness during this stage may result 
in a safety hazard such as potential burns on the user's skin.

6. Pour the goat milk/lye mixture into the large pot with the fat mixture.

7. Use the immersion blender to mix until the batter reaches a light trace. Trace is reached when the mixer can be pulled out of the mixture and a peak appears.

8. Add the fragrance to the mixture.

9. Pour the mixture into the mold.

10. Hit the mold on the ground multiple times to remove air bubbles from the mixture.

11. After 24 hours remove the soap from the mold and cut it to the desired size.

12. Leave the cut soap to sit for 6-8 weeks before use.

\section{Validation Tests and Procedures}

After the design was completed, the team created testing procedures to determine the effectiveness of the final recommended design and analyze its ability to achieve the customer requirements and engineering specifications. The soap-making system passed all of its requirements established by the testing procedures. The four most heavily weighted engineering specifications with their associated customer requirements, testing procedures, and testing results are shown in Table 3.

TABLE 3

ENGINEERING SPECIFICATIONS (ES) WITH ASSOCIATED CUSTOMER REQUIREMENTS (CR), TESTING PROCEDURES, PASSING CRITERIA, AND RESULTS

\begin{tabular}{|c|c|c|c|c|}
\hline ES & CR & Testing Procedure & $\begin{array}{l}\text { Passing } \\
\text { Criteria }\end{array}$ & Result \\
\hline $\begin{array}{l}\text { Batch } \\
\text { Volume }\end{array}$ & $\begin{array}{l}12, \\
13 \\
14,15\end{array}$ & $\begin{array}{l}\text { Measure the physical volume of the batch size soap } \\
\text { mixture in liters. Using a ruler, measure the diameter of } \\
\text { the pot and the height of the mixture in meters. Use the } \\
\text { formula and conversion: } \mathrm{V}=\mathrm{pi} \mathrm{h}^{*} \mathrm{~h}(\mathrm{~d} / 2)^{\wedge} 2^{*} 1000\end{array}$ & $>1 \mathrm{~L}$ & $\begin{array}{l}\text { Pass; the measured } \\
\text { volume for a } \\
\text { single batch was } \\
2.1 \mathrm{~L}\end{array}$ \\
\hline $\begin{array}{l}\text { Hazardous } \\
\text { Waste } \\
\text { Output }\end{array}$ & $\begin{array}{l}5,8 \\
10 \\
11 \\
12 \\
13 \\
14,15\end{array}$ & $\begin{array}{l}\text { Measure the weight of the pot while it is empty and then } \\
\text { with the entire batch of soap mixture. After the soap } \\
\text { mixture has been placed into molds, weigh the pot with } \\
\text { any remaining mixture residue. Subtract the weight of the } \\
\text { empty pot from the other measurements. Next, divide the } \\
\text { weight of the waste by the weight of the original batch. }\end{array}$ & $<15 \%$ & $\begin{array}{l}\text { Pass; the } \\
\text { percentage of } \\
\text { waste measured } \\
\text { for a single batch } \\
\text { was } 4.2 \%\end{array}$ \\
\hline $\mathrm{PH}$ & $\begin{array}{l}1,5 \\
10,13\end{array}$ & $\begin{array}{l}\text { Dissolve } 2 \mathrm{~g} \text { of soap in } 2 \text { cups of } \mathrm{H}_{2} \mathrm{O} \text {. Measure } \mathrm{pH} \text { of the } \\
\text { mixture using a digital } \mathrm{pH} \text { tester. }\end{array}$ & $\begin{array}{l}7.8<\mathrm{pH} \\
<8.4\end{array}$ & $\begin{array}{l}\text { Pass; the average } \\
\mathrm{pH} \text { of the soap was } \\
8.1\end{array}$ \\
\hline Hardness & 1,15 & $\begin{array}{l}\text { Cut a bar of soap to the following dimensions: } 2 \text { "x2"x1". } \\
\text { Place a weight of } 25 \mathrm{lb} \text { on the bar of soap for } 1 \mathrm{~min} \text {. } \\
\text { Measure the width of the bar of soap. }\end{array}$ & $\begin{array}{l}>0.875^{\prime \prime} \\
\text { with no } \\
\text { visible } \\
\text { cracks }\end{array}$ & $\begin{array}{l}\text { Pass; the averaged } \\
\text { thickness } \\
\text { measured after } \\
\text { testing was } 0.979 " \\
\text { with no cracks }\end{array}$ \\
\hline
\end{tabular}




\section{FIELD IMPLEMENTATION AND RESEARCH}

During January 2016, an implementation team led by Kabana and Troen travelled to Uganda to pilot an initial soap-making process based on their own independent research and testing. This team trained TERREWODE employees and Solidarity Group members on their initial process, safety requirements, and ingredients' sourcing. Then, in July 2016, the three OSU capstone team members traveled to Uganda to work with to TERREWODE to further improve the soap-making process, test the improved process, prototype additional improvements, provide recommendations for solar power, and identify additional needs.

\section{Soap-Making Session}

TERREWODE and the capstone team hosted a two-day soap-making session at the TERREWODE Re-Integration Center in Soroti, Uganda. Two Ugandan employees were largely involved in planning and procuring supplies and ingredients for the soap-making. Soap-making participants included 12 Solidarity Group members representing five different groups in the Teso region of Uganda. Each group has dairy goats in their possession, provided by Heifer International in 2015. Over the course of two days, the participants created 264 pieces of soap, or 22 full molds, shown in Figure 6. In collaboration, the capstone team and members experimented with fragrances, batch sizes, measurement tools, cutting templates, and ingredients. The capstone team recognized the importance of participatory design when working with communities in international settings. In this context, it was imperative to have strong engagement with the participating client and have constant awareness of the way their decisions and ideas stem from their culture, language, gender roles, and financial constraints ${ }^{56}$.
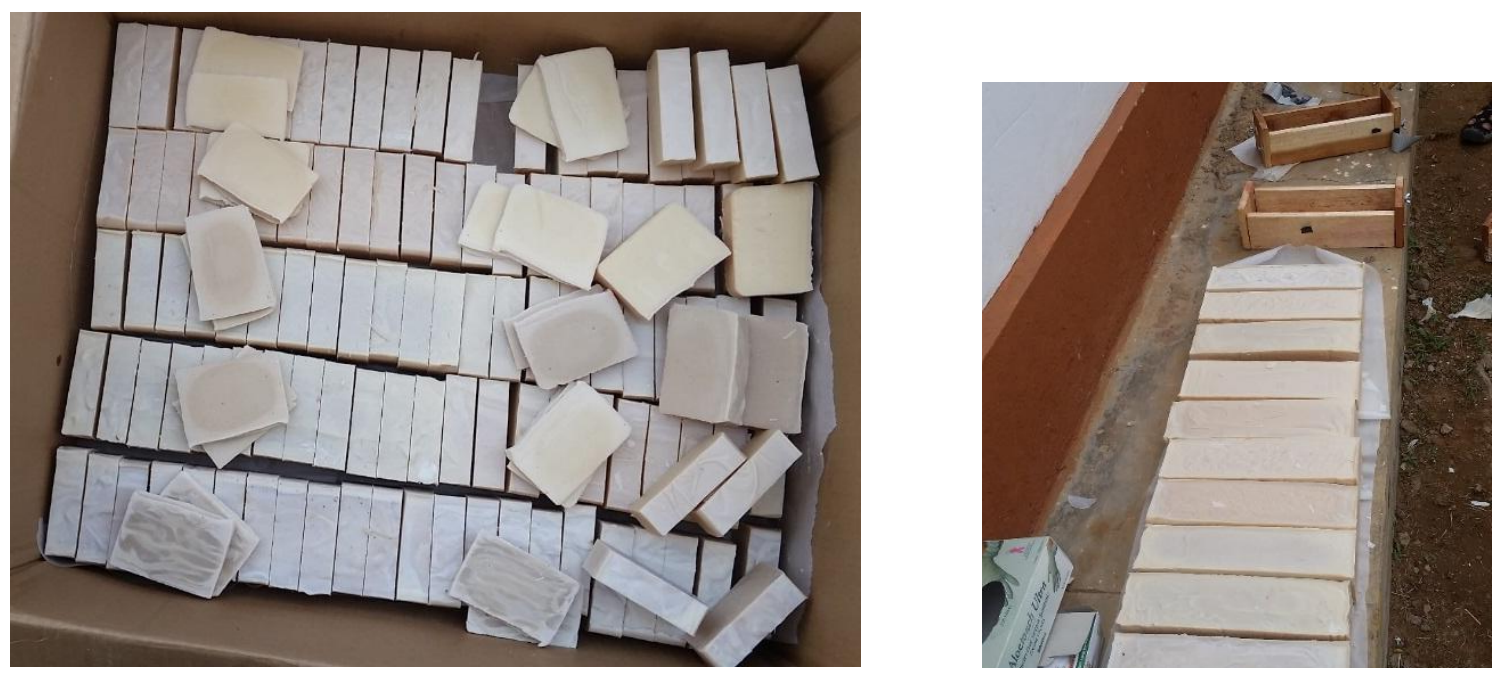

FIGURE 6

PHOTOS OF FINISHED SOAP PIECES (LEFT) AND FULL BARS (RIGHT) IN SOROTI 
The Solidarity Group members made 180 pieces of unscented goat-milk soap. Comparing pairs of batches, the team and members noticed differences in the colors of the soap, ranging from light cream to taupe. The engineering team predicts that the color difference is due to the oils burning in the cookstove or the milk burning in the lye. The members and team agreed that stricter adherence to the timing of each stage would lead to more a uniform product. The remainder of the bars were made with essential oils to add scents. Some of these bars turned out viable while others were unusable, most likely due to an excess of oil. The team and members recommended that TERREWODE receive professional guidance regarding the use of essential oils if they decide to add scent to their product.

While working with TERREWODE employees, it became clear that there was not a convenient way to estimate the quantities of ingredients to purchase. The capstone team created a simple Microsoft Excel tool for the employees to enter the target number of soap pieces and the quantities and prices of ingredient containers. The output included the number of containers required for purchase of each ingredient and the total costs. Although the tool does not include the costs of any labor, transportation, or other expenditures (such as maintaining quality milk or access to water), this will give TERREWODE a simple means to budget for purchasable soap ingredients. A screenshot of the tool is presented in Figure 7.

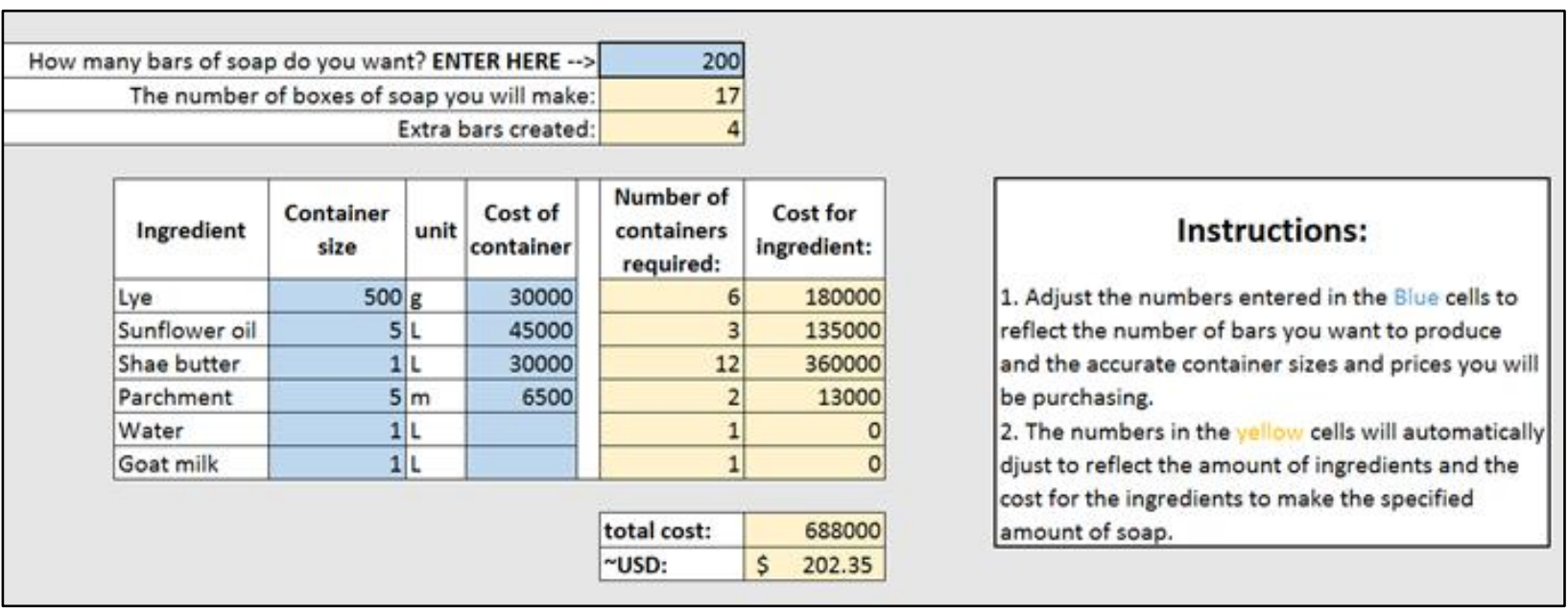

FIGURE 7

\section{SCREENSHOT OF MICROSOFT EXCEL TOOL FOR INGREDIENT PURCHASES}

One concern that presented itself was the use of digital scales for measuring ingredients. About half the soap makers enjoyed using the scales and half did not. One woman claimed that she enjoyed learning a new form of technology - it was evident that this tool empowered her. However, others were concerned about acquiring batteries after depletion and some were reluctant to use the devices due to unfamiliarity. Additionally, weighing the different ingredients was the most time-consuming step in the soap-making process. The capstone team decided to experiment with using volumetric measuring cups instead of weighing the ingredients. The team purchased clear plastic jugs from the local market and, after measuring the proper weight of each 
ingredient, poured the ingredient into the jug and marked the fill line. This form of measurement created uncertainty in the process. Using the newly marked containers, the team experimented with the weights of each ingredient to understand the magnitude of additional uncertainty caused by the volumetric measurement. For five trials of each liquid ingredient, the ingredient was poured into the jug until it reached the drawn fill line. Excluding water, each ingredient's average measurement came in under the target value. Sunflower oil and shea butter were the furthest from the target. This is mostly due to the oil adhering to the sides of the plastic jug.

The team did not have a chance to implement volumetric measuring into the soap-making process with the Solidarity Group members. The team recommended to TERREWODE that if members request volumetric measuring tools, they can implement the marked jugs and perform some trial runs to ensure the additional inaccuracy of ingredient amounts does not adversely affect the final product.

The Solidarity Group members and the capstone team also experimented with the batch size during the soap-making session. Double batches, batches with twice the amount of each ingredient, were created. The members appreciated the double batches because it increased the efficiency of the process without causing any adverse effects on the final product. The team recommended that TERREWODE experiment with triple batches in the future, but not any greater. This recommendation came from testing the capstone team performed in the U.S during the design phase of the project.

Based on their observations, the team decided to create two templates to assist the soap makers during production. One template was used to cut the parchment paper to the correct size to line the inside of the wooden mold. The parchment paper is important because it allows the soap to be easily removed from the mold, while decreasing imperfections. The other template was used to facilitate cutting the soap evenly. The initial training and soap production performed in January resulted in inconsistently sized bars which were not suitable for sale. This template addresses this issue by allowing the user to quickly mark 1-inch increments along the molded soap, which provides a guide while creating the final cuts. Solidarity Group members appreciated using these templates and Emasu, the director of TERREWODE, was especially pleased with the cutting template. Utilizing both these templates will increase efficiency, decrease waste, and create a more consistent final soap product.

During their stay, the soap-making trials were powered from the grid, which was reliable during the two days of testing. Because the local grid can be undependable, the capstone team investigated availability of solar panels, charge controllers, batteries and inverters in the town of Soroti. The team inventoried most of the components available in three popular electronics stores and generated a report with recommendations for the TERREWODE staff for future implementation. Additional recommendations were made by the capstone team including a proposal to redesign the soap storage room and improve the quality of the soap molds. 


\section{Proposed Scaling}

The team assessed the time for each step in the process and designed an assembly line process for TERREWODE to implement when they decide to scale their production. Based on lean manufacturing principles, the nine-person process was designed to be efficient but also communal for the women. The arrangement, shown in Figure 8, is circular in shape, with each process requiring roughly the same amount of time to complete. The process steps are described below:

1. Measure lye using a scale. Measure water using a measuring cup. Pour water into a large mixing bowl and pass to \#2.

2. Pour lye into the mixing bowl with water. Using a spoon, stir the mixture and with a thermometer measure the temperature of the mixture. Once at the correct temperature, pass to \#3.

3. Using a measuring cup, measure the correct amount of goat milk. Pour the goat milk into the lye/water mixture and stir. Pass to \#6.

4. Using Measuring cups, measure the proper amount of sunflower oil and shea butter and place into a pot. Pass the pot to \#5.

5. Heat the pot over the cook stove until the oils are liquid and clear. Pass to \#6.

6. Pour the lye/water/goat milk mixture into the pot of melted oils. Mix using an electric mixer until the soap reaches trace. Pass the pot to \#8.

7. Prepare the molds with parchment paper. Use the template to cut the paper. Fold the edges so that the soap will have sharp corners once it has cooled. Pass the prepared mold to \#8.

8. (Two people) Receive the pot and prepared mold. Pour the mixture into the mold and remove air bubbles.

9. One of the soap makers from \#8 will move the mold to the cooling rack.

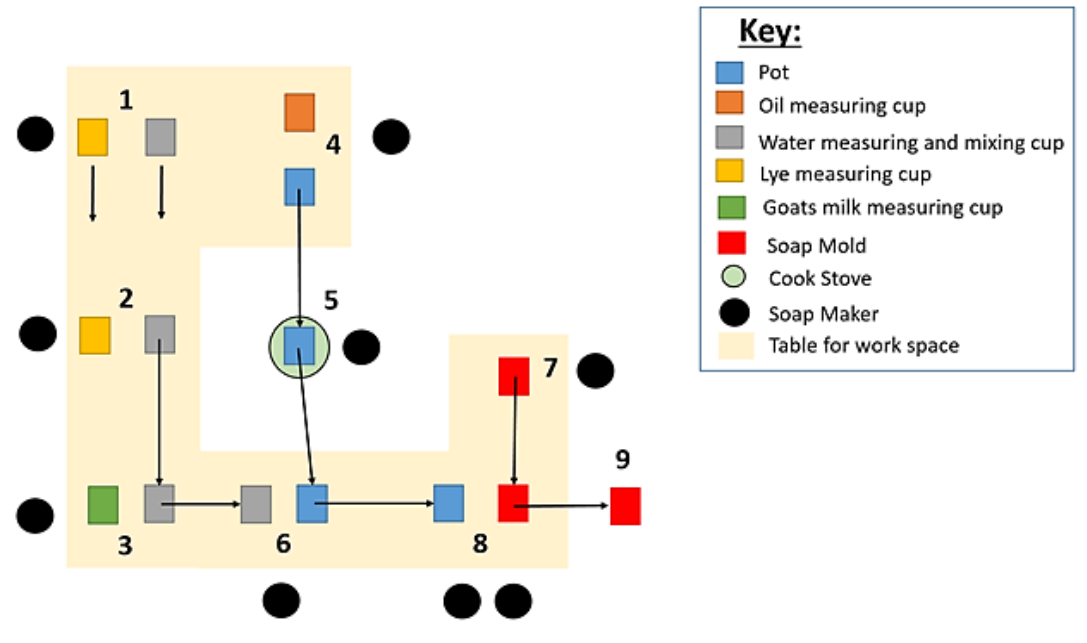

FIGURE 8

PROPOSED MANUFACTURING LINE FOR SOAP-MAKING PRODUCTION 


\section{EDUCATIONAL VALUE}

The learned skills and experiences provided by this project were of high value to the three participating students. During the design and testing phase the students gained communication skills by working with each other and the many stakeholders. They applied the design procedure to a humanitarian context by learning and following the Social Justice Criteria. During the fieldwork phase of the project, the students gained a cross-cultural experience and learned how to implement a project in the field. Although only one student has continued specifically in humanitarian applications of engineering, the other two students are pursuing careers in renewable energy and biomechanics. It is expected that the skills gained from this cross-cultural design experience will be transferable to their future careers.

\section{SUMMARY AND RECOMMENDATIONS}

The OSU engineering team designed, analyzed, and implemented improvements to a soapmaking system that is well suited for TERREWODE in Soroti, Uganda. By following the OSU Capstone design process and the six SJ criteria, the team properly assessed the customer needs and developed appropriate engineering specifications. Choosing the cold process allows for maximum quality, manufacturability, and consistency given the low resource environment where implementation will occur. The testing of solar panels in the United States suggested that a small scale and affordable solar panel system is a practical means of supplying the soap-making process in off grid settings. The field implementation and research performed by the capstone team provided TERREWODE with local solar power system recommendations, process optimization, and proposed scaling guidance. The team effectively communicated the findings of this capstone design project to TERREWODE through personal communication and written reports. The project is expected to enable women of TERREWODE to efficiently produce soap and subsequently may help them attain a more consistent income.

The soap-making project has challenged the OSU University students and faculty to work outside of traditional engineering education by evaluating the context and impact of design decisions. Three mechanical engineering students collaborated with an interdisciplinary group of stakeholders to complete this capstone project. Experiencing an interdisciplinary project with international context aimed at making a positive impact on people lives is not common in senior capstone projects. It is recommended that more capstone projects incorporate humanitarian goals and global context in order to provide more of these experiences.

\section{ACKNOWLEDGEMENTS}

The authors acknowledge the following individuals and organizations for their assistance and opportunity to work on this project: Alice Emasu and other TERREWODE personnel, Ron Severson, Joni Kabana, Dardinelle Troen, Nordica MacCarty, Aprovecho Research Center, and the Phoenix Solar Car team. The authors also thank the Oregon State University College of Engineering Humanitarian Engineering Program for funding portions of this project and the 
International Journal for Service Learning in Engineering, Humanitarian Engineering and Social Entrepreneurship Vol. 12, No. 2, pp. 81-102, Fall 2017

ISSN 1555-9033

International Development Innovation Network (IDIN) for a grant that supported TERREWODE participation.

\section{REFERENCES}

${ }^{1}$ National Academy of Engineering, The Engineer of 2020: Visions of Engineering in the New Century (The National Academies Press, 2004).

${ }^{2}$ R Minnery, “The Future of Impact Design,” Impact Design Hub by Autodesk Foundation (2015), https://impactdesignhub.org/2015/10/14/what-will-impact-design-education-look-like-in-2025/?feature_id=19047

3 A El-Zein, "As Engineers, We Must Consider the Ethical Implications of Our Work," The Guardian (2013), https://www.theguardian.com/commentisfree/2013/dec/05/engineering-moral-effects-technology-impact

${ }^{4}$ A W Astin, L J Vogelgesang, E K Ikeda, and J A Yee, "How Service Learning Affects Students," Higher Education 144 (2000).

5 J Eyler, D E Giles, and J Braxton, “The Impact of Service-Learning on College Students," Michigan Journal of Community Service Learning 4 (1997): 5-15.

${ }^{6}$ L M White, “An Applied International Equine Experience Benefits Employability Skills in Undergraduate Students," NACTA Journal 60:1 (2016): 7-12.

7 E Jones, "Internationalization and Employability: The Role of Intercultural Experiences in the Development of Transferable Skills," Public Money \& Management 33:2 (2013):95-104.

8 R Bhandari and P Chow, Trends in Science and Technology Study Abroad from Open Doors (Institute for International Education, 2009).

9 C Zukin and M Szeltner, "Talent Report: What Workers Want in 2012," Netimpact (2012), http://www.netimpact.org/whatworkerswant

${ }^{10}$ B Amadei and R Sandekian, "Model of Integrating Humanitarian Development into Engineering Education," Journal of Professional Issues in Engineering Education \& Practice 136:2 (2010): 84-92.

${ }^{11}$ Engineers Without Borders USA, “Strategic Plan 2015 - 2020,” http://www.ewb-usa.org/files/2015/07/2015Strategic-Plan.pdf

${ }^{12}$ Engineers Without Borders USA, "Find a Chapter," https://www.ewb-usa.org/myewb/find-a-chapter/

${ }^{13}$ K Strand, S Marullo, N Cutforth, R Stoecher, and P Donohue, Community-Based Research and Higher Education (Jossey-Bass, 2003).

14 J A Leydens and J C Lucena, "Social Justice: A Missing, Unelaborated Dimension in Humanitarian Engineering and Learning Through Service," International Journal for Service Learning in Engineering 9:2 (2014): 1-28.

${ }^{15}$ Colorado School of Mines, "Humanitarian Engineering," http://bulletin.mines.edu/undergraduate/interdisciplinaryminors/humanitarianengineering/

${ }^{16}$ Penn State College of Engineering, "Humanitarian Engineering and Social Entrepreneurship," http://sites.psu.edu/hese/

${ }^{17}$ Ohio State University, "Humanitarian Engineering Center," https://osuhe.engineering.osu.edu/

${ }^{18}$ The University of California, Berkeley, "Development Impact Lab," http://dil.berkeley.edu/

${ }^{19}$ Massachusetts Institute of Technology, "MIT D-Lab,” https://d-lab.mit.edu/

${ }^{20}$ University of Canterbury, "Diploma in Global Humanitarian Engineers," http://www.canterbury.ac.nz/futurestudents/qualifications-and-courses/undergraduate-certificates-and-diplomas/diploma-in-global-humanitarianengineering/

${ }^{21}$ Australian National University, "Humanitarian Engineering Opportunities," https://cecs.anu.edu.au/currentstudents/humanitarian-engineering-design-summits

22 T Colledge, "Engineering and Engaged Scholarship at Penn State Part I: The Rationale," International Journal for Service Learning in Engineering, Special Edition (2014): 97-113.

${ }^{23} \mathrm{~J}$ Keshwani and K Adams, "Cross-Disciplinary Service-Learning to Enhance Engineering Identity and Improve Communication Skills," International Journal for Service Learning in Engineering 12:1 (2017): 41-61.

${ }^{24}$ United Nations, "Sustainable Development Goals," (2015), http://www.un.org/sustainabledevelopment/sustainable-development-goals/ 
International Journal for Service Learning in Engineering, Humanitarian Engineering and Social Entrepreneurship Vol. 12, No. 2, pp. 81-102, Fall 2017

ISSN 1555-9033

${ }^{25}$ UNESCO, "Engineering: Issues, Challenges and Opportunities for Development," United National Educational Scientific and Cultural Organization (2010).

${ }^{26}$ Arup, "Arup Financial Statements 2013," http://www.arup.com/

${ }^{27}$ V Choudhary, M Dewhurst, and A Kshirsagar, How Western Multinationals Can Organize to Win in Emerging Markets (McKinsey \& Company, 2013).

${ }^{28}$ S Manning, "Customizing Clusters: On the Role of Western Multinational Corporations in the Formation of Science and Engineering Clusters in Emerging Economies," Economic Development Quarterly 22:4 (2008): 316323.

${ }^{29}$ M Floyd, "Gift Establishes Professorship in 'Humanitarian Engineering' at Oregon State," OSU News and Communications (2015).

${ }^{30}$ Oregon State University, "Humanitarian Engineering,” http://humanitarian.engineering.oregonstate.edu/

${ }^{31}$ L L Wall, J A Karshima, C Kirschner, and S D Arrowsmith, “The Obstetric Vesicovaginal Fistula: Characteristics of 899 Patients From Jos, Nigeria," American Journal of Obstetrics and Gynecology 190:4 (2004): 1011-1016.

${ }^{32}$ B J Ruder, Shattered lives: Understanding Obstetric Fistula in Uganda, (Oregon State University, 2012).

${ }^{33}$ N M Nour, "Child Marriage: A Silent Health and Human Rights Issue," Reviews in Obstetrics \& Gynecology 2:1 (2009): 51-56.

${ }^{34}$ H S K Nsubuga, "Small Ruminants: Goat and sheep in Uganda," Proceedings of the 3rd Biennial Conference of the African Small Ruminant Research Network (1994): 1-4.

${ }^{35}$ E Ssewannyana, "Strategies for Management of Animal Genetic Resources in Uganda," Uganda Journal of Agricultural Sciences 9 (2004): 888-892.

${ }^{36}$ S Jimmy, M David, K R Donald, and M Dennis, "Variability in Body Morphometric Measurements and Their Application in Predicting Live Body Weight of Mubende and Small East African Goat Breeds in Uganda," Middle-East Journal of Scientific Research 5:2 (2010): 98-105.

${ }^{37}$ N Houtman, "Lessons in Resilience," Terra Research Magazine (2016).

${ }^{38}$ A Grosso, The Everything Soapmaking Book: Recipes and Techniques for Creating Colorful and Fragrant Soaps, (Avon, MA: Adams Media, 2013): 69 - 132.

39 A A Warra, "A Report on Soap Making in Nigeria Using Indigenous Technology and Raw Materials," African Journal of Pure and Applied Chemistry 7:4 (2013): 139-145.

${ }^{40}$ African Development Bank Group, "Rural Enterprises Project II in Ghana - Transforming the Lives of the Rural Poor," (2012), https://www.afdb.org/en/news-and-events/rural-enterprises-project-ii-in-ghana-transforming-thelives-of-the-rural-poor-9203/

41 The Zimbabwean, "Sweet Smell of Success," (2015), http://www.thezimbabwean.co/2015/04/sweet-smell-ofsuccess-2/

${ }^{42}$ L Plesent, S Lincoln, “Training Manual for a Village Soap-Making Operation by Vermont Soap,” (2012), http://vermontsoap.com/training-manual-for-a-village-soap-making-operation/

${ }^{43}$ EWB-UK, "Training Hand Over Pack: Cold Process Soap Making," https://www.yumpu.com/en/document/view/36474897/cold-process-soap-making-ewb-uk-training-hand-overpack

44 AllAfrica, "Uganda: Kyambogo Student Starts Small-Scale Soap Industry,” (2007), http://allafrica.com/stories/200701170870.html

45 Oregon State University Course Description, "ME 497-498: MIME Capstone Design," http://mime.oregonstate.edu/content/me-497-498-mime-capstone-design

${ }^{46}$ J R Hauser, "How Puritan-Bennett Used the House of Quality," Sloan Management Review: Reprint Series 34:3 (1993):60-70.

${ }^{47}$ L Leydens, "Social Justice: A Missing, Unelaborated Dimension in Humanitarian Engineering and Learning Through Service," International Journal for Service Learning in Engineering 9:2 (2014): 1-14.

${ }^{48}$ B Ruder, interview by Grace Burleson, Brian Butcher, Brianna Goodwin, November 2015.

${ }^{49}$ R Severson, interview by Grace Burleson, Brian Butcher, Brianna Goodwin, November 2015.

${ }^{50} \mathrm{~N}$ MacCarty, D Still, and D Ogle, "Fuel Use and Emissions Performance of Fifty Cooking Stoves in the Laboratory and Related Benchmarks of Performance," Energy for Sustainable Development 14 (2010): 161-171.

${ }^{51}$ Climate Data, "Climate: Uganda," https://en.climate-data.org/info/sources/ 
International Journal for Service Learning in Engineering, Humanitarian Engineering and Social Entrepreneurship Vol. 12, No. 2, pp. 81-102, Fall 2017

ISSN 1555-9033

${ }^{52}$ Aprovecho Research Center, "Laboratory Emissions Monitoring Systme (LEMS),” http://aprovecho.org/portfolioitem/laboratory-emissions-monitoring-system/

${ }^{53}$ Occupational Safety \& Health Administration, "Table Z-1 Limits for Air Contaminants," (2015).

${ }^{54}$ P M Murphy, S Twaha, and I S Murphy, "Analysis of the Cost of Reliable Electricity: A New Method for Analyzing Grid Connected Solar, Diesel and Hybrid Distributed Electricity Systems Considering an Unreliable Electric Grid, with Examples in Uganda," Energy 66 (2014): 523-534.

${ }^{55}$ K R Ajao, K Mustapha, M R Mahamood, and M O Iyanda, "Design and Development of a Pedal-powered Soap Mixer," New York Science Journal 3:1 (2010): 2-5.

${ }^{56}$ K Villars and C Magoon, "Water Supply and Treatment Design in Rural Belize: A Participatory Approach to Engineering Action Research,” International Journal for Service Learning in Engineering 5:1 (2010): 47-63. 